\title{
Psenulus pallipes (Panzer, 1798), an adventive wasp species (Apoidea, Crabronidae) newly recorded in the fauna of Chile
}

\author{
Brunno B. Rosa ${ }^{1}$, Gabriel A. R. Melo ${ }^{1}$ \\ 1 Laboratório de Biologia Comparada de Hymenoptera, Departamento de Zoologia, Universidade Federal do Paraná, Caixa Postal 19020, Curitiba, \\ Brazil, 81530-980. \\ Corresponding author: Brunno B. Rosa, brunnobueno27@gmail.com
}

\begin{abstract}
We document the presence of the Palearctic Psenulus pallipes (Panzer, 1798) in Chile for the first time. We believe this represents an adventive population introduced into the Neotropical region most likely by accidental human transportation of nests. A map of distribution in Chile, illustrations of external morphology, and a discussion of morphological features to distinguish the introduced taxon from the Neotropical species are presented.
\end{abstract}

\section{Key words}

Pemphredoninae; exotic species; Hymenoptera.

\section{Introduction}

With about 170 described species, the wasp genus Psenulus is the largest in the Pemphredoninae (Apoidea, Crabronidae), presenting the greatest diversity in the Oriental, Ethiopic, and Palearctic regions (Bohart and Menke 1976, Pulawski 2018, Rosa and Melo unpubl. data). Psenulus has an unusual world distribution by having less diversity in the Neotropical region than other groups of Pemphredoninae (and several other groups of crabronids). Recently, 9 new species have been recognized, totaling 12 species in this region (Rosa and Melo unpubl. data). An exploratory phylogenetic investigation carried out by Rosa and Melo (unpubl. data) showed that both the Neotropical and the Holarctic fauna form separate monophyletic groups.

In the present note, we report an adventive population of Psenulus pallipes (Panzer, 1798), which is also newly recorded in Chile. A map with this species' Chilean distribution, illustrations of the external morphology, and a discussion of the morphological features to distinguish $P$. pallipes from the Neotropical species are presented.

\section{Methods}

Materials of Psenulus pallipes from the following institutions were examined: American Museum of Natural History (New York, USA; AMNH) and the Bee Biology and Systematics Laboratory (Logan, Utah, USA; BLCU). We used the identification key of Schmid-Egger (2016) and compared the Chilean specimens with 1 female of $P$. pallipes and 1 male and 1 female of $P$. chevrieri (Tournier, 1889) from Germany. These Old World specimens have been kindly provided by C. Schmid-Egger and are currently deposited in the Coleção Entomológica Pe. Jesus Santiago Moure, Departamento de Zoologia, Universidade Federal do Paraná (DZUP). 

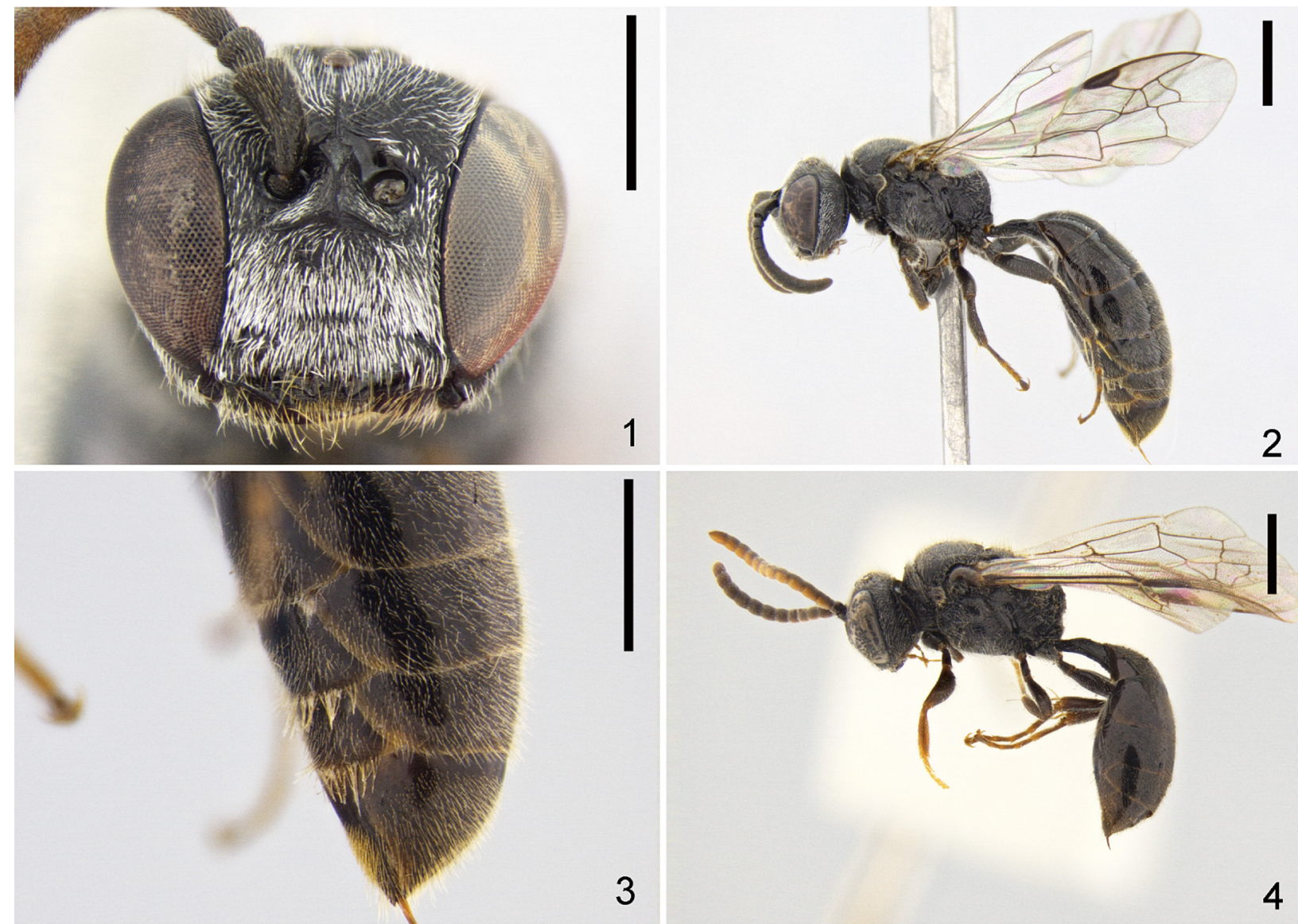

Figures 1-4. Studied specimens of Psenulus pallipes (Panzer, 1798) from Chile deposited in the American Museum of Natural History; both specimens from Las Trancas, Nuble. 1. Head of female, frontal view. 2. Habitus of female, lateral view. 3. Metasoma of female, lateral view, specialized spinnerets on sternites IV and V. 4. Habitus of male, lateral view.

The general morphological terminology follows Bohart and Menke (1976). The color images were obtained on a camera Leica DFC295 connected to a stereomicroscope Leica M125 and processed by Zerene Stacker software. The data from labels of examined specimens were transcribed (see Materials examined), and a backslash $(\backslash)$ was used to indicate a new line of text on the label, and the single quotation marks enclose different labels associated with a specimen.

\section{Results}

\section{Psenulus pallipes (Panzer, 1798)}

Sphex pallipes Panzer, 1798: 52, female holotype or syntypes, Germany (unknown repository, not examined).

Further synonymic list, see Pulawski (2018).

This species belongs to the Holarctic group and is widely distributed in the Palearctic region. The Holarctic clade is supported by the following characters: lower orbital margin shorter than width of base of mandible; F2 wider than long; separation between metasomal petiole and rest of tergum I indistinct; sternum II with a depressed triangle-shaped area; posterior margin of sternum IV straight (Rosa and Melo unpubl. data).

Psenulus pallipes (Figs. 1-4) is easily distinguished from all Neotropical species by the wide frontal carina (Fig. 1), whose dorsal surface is excavated and crossed by fine transverse striation, by its coarse punctation on the head and mesosoma, the carinate upper portion of the frons, vertex and gena, pilose base of the propodeum, strongly carinate base of the propodeum in females, possession of specialized silk spinnerets along posterior margin of sterna IV and V (Fig. 3), and the pygidial plate entirely delimited by carinae.

Examined material. Chile, Curico: 2 (BLCU), 'CHILE Curico prov. $\backslash 10 \mathrm{~km}$ E.Curico, Fardo, \Los Niches, Le Borregal $\backslash 9-21$ Nov 97 G.Barria $\backslash 35.0665^{\circ} \mathrm{S} 71.1226^{\circ} \mathrm{W}$ '. Malleco: 19 (AMNH), 'CHILE,Malleco: \ Monte Mila, nr. \Victoria, \January 7,1983 \Luis E. Peña’. Nuble: 19 (AMNH), 'CHILE, Nuble:Las \Trancas, SE Recinto \in Chillen area, \1100 m, Feb.1987\Luís E. Peña'; $13 \hat{\jmath}$ (AMNH), 'CHILE, Nuble: Las \ Trancas, SE Recinto \in Chillen area, \February $1987 \backslash$ Luís E. Peña'; 19 (AMNH), 'CHILE: Ñuble Prov., \Las Trancas, E.Recinto \22-I-1987 L. Peña’; $2 \widehat{\jmath}$ (AMNH), same data; 1 ㅇ (AMNH), 'CHILE: VIII: Nuble \Chillán, Las Trancas $\backslash 1100 \mathrm{~m}$, Jan $1987 \backslash$ L. Peña'. Santiago: $1 \widehat{\jmath}$ (AMNH), 'CHILE, Santiago: \Renca, Dec. $1984 \backslash$ Luís E. Peña'; $2 q$ (AMNH), 'CHILE,Santiago: \Macul, \Nov. II, $1974 \backslash$ Luis E. Peña'. Valparaíso: $6 \bigcirc$ (AMNH), 'CHILE - XI.81 $\backslash$ Valparaíso \Viña del Mar $\backslash$ Tosti-Croce' 'Psenulus $\backslash$ pallipes $\backslash$ (Panzer) $\backslash$ Fritz det. 93'; 4ðิ (AMNH), same data, except 'X.83'; 8 ○े (AMNH), 'CHILE - XI.83 \Viña del 


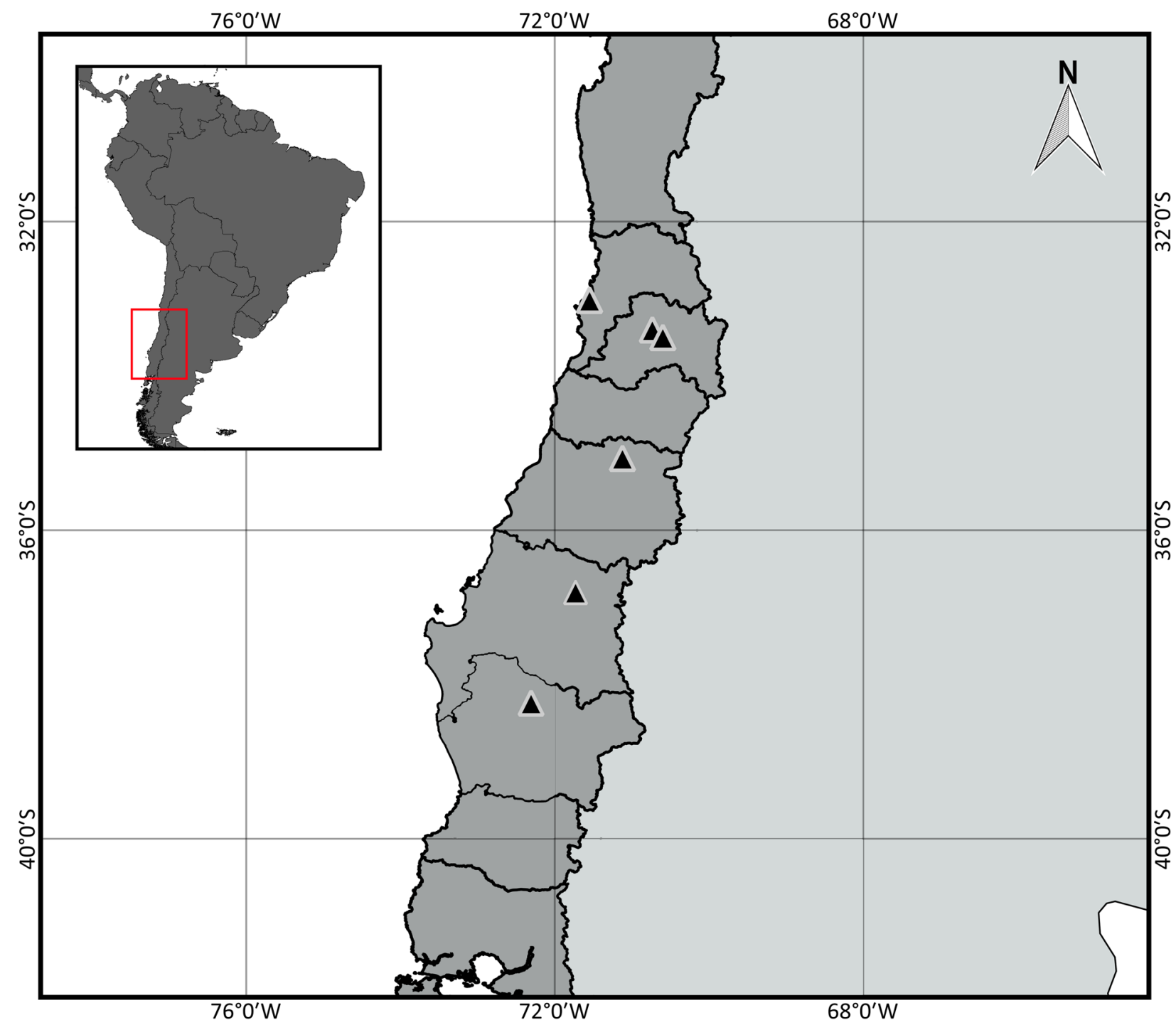

Figure 5. Distribution of the studied specimens of Psenulus pallipes (Panzer, 1798) in Chile. The map shows the delimitation of the Chilean regions.

Mar $\backslash$ Tosti-Croce' 'Psenulus $\backslash$ pallipes $\backslash$ (Panzer) $\backslash$ Fritz det. 93'; 1ठ̄(AMNH), same data, except 'Psenulus \pallipes $\backslash$ (Panzer) $\widehat{\jmath} \backslash$ det. W.J.Pulawski 1992’; 2 (AMNH), 'V Region \Viña del Mar \NOV. 1981' 'Psenulus \pallipes $\backslash$ (Panzer) $\backslash$ Fritz det. 93'; $6 \widehat{\jmath}$ (AMNH), same data; 19 (AMNH), same data, except 'Psenulus $\backslash$ pallipes $\backslash$ (Panzer) $q \backslash$ det. W.J.Pulawski 1992'; 1q (AMNH), 'J.JIMENEZ E. \Nov.83 \Viña del Mar'.

\section{Discussion}

Chile has an interesting history of introduced species of aculeate wasps of Palearctic origin, including the social vespids Vespula germanica (Fabricius, 1793) (Pena et al. 1975, as Vespula maculifrons (Buysson)), Vespula vulgaris (Linnaeus, 1758) (Barrera Medina and Vidal Muñoz 2013), and Polistes dominulus (Christ, 1791) (Gonzales Rodriguez 1989, as Polistes gallicus (Linnaeus)), the solitary vespid Eumenes dubius (de Saussure, 1852) (Barrera-Medina and Lukhaup 2015) and the solitary sphecid Sceliphron curvatum (Smith, 1870) (Barrera-Medina and
Garcete-Barrett 2008). The record of Psenulus pallipes is the first representing an introduced species belonging to the family Crabronidae in this country.

The studied specimens of Psenulus pallipes were collected in 5 of the 15 regions of Chile (Fig. 5), belonging to 5 different provinces: Curico (VII Region), Malleco (XIX Region), Ñuble (VIII Region), Santiago (RM Region), and Valparaíso (V Region). These Chilean regions are within the Mediterranean and temperate zones of the country, between latitudes $32^{\circ} \mathrm{S}$ and $48^{\circ} \mathrm{S}$ (Nahuelhual et al. 2007, Muñuz et al. 2016). Psenulus pallipes occurs in areas of the Old World having similar temperate climates (Schmid-Egger 2016, Pulawski 2018). Its presence in Chile is considered here as representing an adventive population introduced into the Neotropical region most likely by accidental human transportation of nests.

\section{Acknowledgements}

We thank Christian Schmid-Egger for donating specimens of Psenulus to the DZUP collection, James Carpenter for 
support during a visit to the AMNH, and Kevin Williams for his help in obtaining additional specimens for this study. Financial support has been provided by Conselho Nacional de Desenvolvimento Científico e Tecnológico (grant GARM 309641/2016-0; BBR 130397/2013-0).

\section{Authors' Contributions}

BBR and GARM examined the specimens and checked the identification and characterization of species; BBR wrote the text, with contributions from GARM, and made the images, maps and prepared the Figure 5.

\section{References}

Barrera-Medina R, Garcete-Barrett BR (2008) Sceliphron curvatum (Smith, 1870) una nueva especie de Sphecidae (Hymenoptera) introducida en Chile. Revista Chilena de Entomología 34: 69-72.

Barrera-Medina R, Luckhaup C (2015) Eumenes Latreille, 1802 (Hymenoptera: Vespidae), un nuevo género para Chile. Boletín de la Sociedad Entomológica Aragonesa 56: 309-311.

Barrera-Medina R, Vidal Muñoz C (2013) Primer reporte de Vespula vul- garis (Linnaeus, 1758) (Hymenoptera: Vespidae) en Chile. Boletín de la Sociedad Entomológica Aragonesa 52: 277-278.

Bohart R R, Menke AS (1976) Sphecid Wasps of the World: A Generic Revision. University of California Press, Berkeley, 695 pp.

González Rodríguez H (1989) Insectos y ácaros de importancia agrícola y cuarentenaria en Chile. Universidad de Chile, Impresora Ograma SA, Santiago, $310 \mathrm{pp}$.

Muñoz AA, González-Reyes A, Lara A, Sauchyn D, Christie D, Puchi P, Urrutia-Jalabert R, Toledo-Guerrero I, Aguilera-Betti I, Mundo I, Sheppard PR, Stahle D, Villalba R, Szejner P, LeQuesne C, Vanstone J (2016) Streamflow variability in the Chilean TemperateMediterranean climate transition $\left(35^{\circ} \mathrm{S}-42^{\circ} \mathrm{S}\right)$ during the last 400 years inferred from tree-ring records. Climate Dynamics 47(12): 4051-4066. http://doi: 10.1007/s00382-016-3068-9

Nahuelhual L, Donoso P, Lara A, Núñez D, Oyarzún C, Neira E (2007) Valuing ecosystem services of Chilean temperate rainforests. Environment, Development and Sustainability 9: 481-499. https://doi. org/10.1007/s10668-006-9033-8

Peña L, Pérez De Arce R, Cartagena L (1975) La presencia de Vespula maculifrons (Buysson) (Hymenoptera: Vespidae) en Chile. Revista Chilena de Entomología 9: 167-168.

Pulawski WJ (2018) Catalog of Sphecidae sensu lato. http://research. calacademy.org/ent/catalog_sphecidae. Accessed on: 2018-3-9.

Schmid-Egger C (1997) The Psenulus pallipes species group in Central Europe (Hymenoptera, Crabronidae). Ampulex 8: 40-44. 